$\begin{array}{ll}\text { Variants } & \begin{array}{l}\text { Variants } \\ \text { The Journal of the European Society for Textual } \\ \text { Scholarship }\end{array}\end{array}$

12-13 | 2016

Varia

\title{
Luigi Ferreri, L'Italia degli Umanisti: Marco Musuro
}

\section{Alessio Assonitis}

\section{OpenEdition}

\section{Journals}

\section{Electronic version}

URL: http://journals.openedition.org/variants/385

DOI: $10.4000 /$ variants.385

ISSN: 1879-6095

\section{Publisher}

European Society for Textual Scholarship

\section{Printed version}

Date of publication: 31 December 2016

Number of pages: 246-249

ISSN: 1573-3084

\section{Electronic reference}

Alessio Assonitis, « Luigi Ferreri, L'ttalia degli Umanisti: Marco Musuro », Variants [Online], 12-13| 2016, Online since 01 May 2017, connection on 23 September 2020. URL : http://journals.openedition.org/ variants/385; DOI : https://doi.org/10.4000/variants.385

This text was automatically generated on 23 September 2020 .

The authors 


\title{
Luigi Ferreri, L'Italia degli Umanisti: Marco Musuro
}

\author{
Alessio Assonitis
}

\section{REFERENCES}

Luigi Ferreri. L'Italia degli Umanisti: Marco Musuro. Turnhout: Brepols, 2014. XXX + 695 pp. ISBN 978-2-503-55483-9.

Luigi Ferreri's study on Marcus Musurus is certainly not intended for students broaching the topic of Renaissance Humanism for the first time. The breadth and depth of this project - not to speak of the toil and accuracy with which it was put together make this an impeccable piece of scholarship: one that exhaustively sheds light on the complex mechanisms of late fifteenth- and early sixteenth-century humanist discourse and that establishes the scholarly coordinates of this understudied editor, copyist, translator, educator, book collector, and poet.

2 In his introduction, Ferreri spells out the methodological framework that characterized his research. The author immediately delineates the philological and historical cruces that have hitherto plagued scholarship on Musurus and on the humanist milieus in which he operated. Much emphasis is placed on Musurus' modus operandi, particularly on the editing, annotation, and translation of manuscript texts, and their curation and transformation into printed products. Most importantly, he charts the extent to which Musurus contributed to the dissemination of Greek culture in Italy (and, in turn, in Europe) and the trajectories of his cultural legacy. In order to do so, he reassess Musurus' known production and, on the basis of such careful scrutiny, proposes new attributions or debunks old ones, which he painstakingly backs up, whenever possible, with direct and indirect documentary evidence. Such philological, historical and historiographical constructs are complemented by his connoisseurship and by a deep understanding of Musurus' complete oeuvre. 
3 Ferreri's vita of Musurus (33-73) builds upon and improves Annaclara Cataldi Palau's 2004 biographical account (Italia medioevale e umanistica, XLV, 2004, pp. 295-369) and Paolo Pellegrini's 2012 entry in the Dizionario Biografico degli Italiani (vol. 77, 2012, pp. 576-83). Though not delving thoroughly in archival sources (perhaps this is the only lacuna of this study), Ferreri establishes a chronology of this Greek humanist also on the basis of indications found in manuscripts and edited texts (see 655-56). By doing so, he questions and, in some cases, revises, crucial dates in Musurus' life and career, especially the ones that were not supported by the necessary factual evidence. Born around 1470 in Candia - Crete, at the time, was under Venetian rule - Musurus arrived to Italy in 1492 with his teacher Janus Lascaris, who was sent off to the Levant by Lorenzo de' Medici in search of Greek manuscripts and scholars to bring back to Florence. Shortly after Piero de' Medici's exile in 1494, Musurus relocated to Venice where he collaborated with Aldo Manuzio until his death in 1515. This period was marked not only by an extensive production of Greek editions published by the Aldine press, but also by intense research and teaching. From 1503 to 1509, Musurus lectured at the Studio in Padua and, from 1512 to 1516, at Scuola di San Marco in Venice. Impressive, as Ferreri points out (pp. 48-50), was the roster of prominent students that worked under his tutorship. In 1516, he moved to Rome where he was involved in the creation the Gymnasium at Monte Cavallo, founded under the auspices of Leo X, in the house of Angelo Colocci. This Greek college formed a formidable humanist axis with the nearby Dominican convent of San Silvestro al Quirinale, which not only featured Lascaris and Zacharias Calliergi, but also scholars, reformers and poets such as Paolo Giustiniani, Zanobi Acciauoli, Sante Pagnini, Niccolo Schömberg, and Pietro Bembo. One of the great merits of Ferreri's volume is the mapping of scholarly networks in Medici Florence, Republican Venice and Papal Rome, and the pivotal role that Musurus played between these centers. It is in this fervid intellectual environment that Musurus met an untimely death in October 1517.

4 The premises that the author establishes in the introduction and biographical account are substantiated in the final three chapters, which constitute the bulk of this book. In the first section - "Edizioni" - Ferreri meticulously presents Musurus' catalogue raisonné of printed volumes, of safely attributed works, of secure and probable collaborations on book projects, and of works that have falsely been attributed to him. The author describes and annotates each of these volumes; tackles the most pressing philological questions; and provides Italian translations for Greek and Latin frontispieces, colophons, dedicatory letters and poems, prefaces, etc. The quantity and quality of information for each entry - particularly for those volumes whose authorship is uncertain - are especially useful for philologist and book historians, but also for scholars working on Lascaris and Manuzio. In the second chapter - "Musuro Insegnante" - Ferreri reconstructs Musurus' courses during his tenure at Padua and, to lesser degree, Venice, from recollectae and snippets of comments, transcriptions, and letters written by his students. Though the amount of documentary evidence discussed in this chapter is certainly scanty (scholars on Musurus may want to pick up from where Ferreri left off and begin to explore archival collections, much in the tradition of Armando Verde's seminal work on the Studio Fiorentino), this section will prove useful to scholars working on Renaissance studia and on the formation of intellectual contubernia in Italy. The final chapter, "La Biblioteca di Musuro", examines manuscripts copied (in full or in part) by Musurus; manuscripts and printed volumes that he 
annotated; his Latin translations of Johannes Philoponus, housed at the Vatican Library; and manuscripts that ended up in other collections. Particularly illuminating is Ferreri's introductory essay to this section (457-69), in which he engages in a detailed discussion of bibliographic and codicological matters and reviews David Speranzi's Marco Musuro. Libri e scrittura (Rome, 2013), which touches upon many aspects featured this chapter.

5 Ferreri's Marco Musuro - the first volume in the Brepols series "Europa Umanistica: L'Italia degli Umanisti" - is a work that will be appreciated by Greek philologists. Historians of the Renaissance, on the other hand, may find it too deeply immersed in the thick of Humanist discourse. The amount of technical information recorded therein may seem overwhelming at first, but allows the author to ensure that Musurus retain the role of key protagonist of that generation of Greek scholars that made Italy the center of Greek studies in the first part of the Cinquecento.

\section{AUTHORS}

\section{ALESSIO ASSONITIS}

Alessio Assonitis received his doctoral degree in Renaissance art history from Columbia University in 2003. He has taught at Columbia University, Barnard College, Herron School of Art, and the Christian Theological Seminary. In 2003-4, he served as Allen Whitehill Clowes Curatorial Fellow at the Indianapolis Museum of Art. He arrived at the Medici Archive Project in the autumn of 2004 on a National Endowment for the Humanities Fellowship. He became MAP Research Director in 2009 and Director in 2011. 